\title{
Pengaruh inflasi dan suku bunga dan nilai tukar rupiah serta jumlah uang beredar terhadap return saham
}

\author{
La Rahmad Hidayat ${ }^{1}$, Djoko Setyadi ${ }^{2}$, Musdalifah Azis ${ }^{3}$ \\ Fakultas Ekonomi dan Bisnis Universitas Mulawarman, Samarinda \\ 1Email: rahmadhidayat325@gmail.com \\ ${ }^{2}$ Email: musdalifah.azis@gmail.com \\ ${ }^{3}$ Email: djoko.setyadi@gmail.com
}

\begin{abstract}
Abstrak
Pengambilan sampel menggunakan purposive sampling dan di dapatkan 24 saham yang memenuhi kriteria dari 45 saham Indeks LQ 45 sebagai sampel. Sehingga, jumlah sampel yang diteliti adalah 144 saham selama 6 tahun. Metode penelitian yang digunakan adalah analisis regresi linear berganda yang menguji signifikan atau tidaknya variabel bebas terhadap variabel terikat. Berdasarkan hasil diketahui bahwa R menunjukkan bahwa terdapat hubungan yang ideal dari Inflasi, Suku Bunga, Nilai Tukar Rupiah dan Jumlah Uang Beredar terhadap Return saham pada Indeks LQ 45. R square menunjukkan bahwa inflasi, suku bunga, nilai tukar rupiah dan jumlah uang beredar dapat menerangkan return saham pada Indeks LQ 45. Berdasarkan uji F menunjukkan bahwa inflasi, suku bunga, nilai tukar rupiah dan jumlah uang beredar mempunya pengaruh yang signifikan terhadap returm saham indeks LQ 45 yang terdaftar pada Bursa Efek Indonesia. Hasil uji T menunjukkan bahwa variabel tingkat inflasi mempunyai pengaruh negative signifikan terhadap return saham dan suku bunga mempunyai pengaruh positif signifikan terhadap return saham sedangkan nilai tukar rupiah dan jumlah uang beredar mempunyai pengaruh yang tidak signifikan terhadap return saham indeks LQ 45 yang terdaftar pada Bursa Efek Indonesia.
\end{abstract}

Kata Kunci: Return Saham; Tingkat Inflasi; Tingkat Suku Bunga

\section{Influence of inflation and interest rate and rupiah exchange rate and money supply to stock return}

\begin{abstract}
Its Sampling using purposive sampling and get the 24 stocks that meet the criteria of 45 stocks LQ 45 as a sample. Thus, the number of samples studied was 144 shares for 6 years. The method used is multiple linear regression analyzes that examine whether or not a significant variable - the independent variable on the dependent variable. Based on the results known that $\mathrm{R}$ indicates that there is an ideal relationship of Inflation, Interest Rate, Exchange Rate and Money Supply toward to Return shares in LQ 45. R square indicates that the variable inflation rates, interest rates, the value of exchange rate and the money supply can explain the variable return shares at LQ 45 index. Based on F test indicates the same that the variable inflation rate, interest rate, exchange rate and money supply have a significant influence on shares returns in LQ 45 listed on Indonesia Stock Exchange. The results of $T$ test showed that the rate of inflation significant and negative effect on shares returns and interest rates positive and significant effect on shares returns while exchange Rate and the money supply no significant effect on shares returns in LQ 45 Listed on Indonesia Stock Exchange.
\end{abstract}

Keywords: stock return; Inflation; Interest Rate 


\section{PENDAHULUAN}

Setiap negara di dunia ini pasti memiliki pasar modal, terkecuali negara dengan sistem sosialis atau tertutup. Investasi melalui pasar modal selain memberikan tingkat pengembalian investasi tersebut, juga mengandung resiko. Besar kecilnya resiko di pasar modal sangat dipengaruhi oleh keadaan negara khususnya di bidang ekonomi, politik dan sosial serta keadaan dalam perusahaan yang juga dapat mempengaruhi naik atau turunnya saham. Salah satu kegiatan investasi yang dapat dipilih oleh investor adalah berinvestasi di pasar modal di Indonesia, investor yang berminat untuk berinvestasi di pasar modal dapat berinvestasi di Bursa Efek Indonesia (BEI). Indeks LQ 45 bisa digunakan untuk mengukur kinerja pasar saham di BEI secara khusus, dimana investor bisa fokus berinvestasi pada saham-saham top dengan menggunakan Indeks LQ 45. Blue chip atau saham unggulan merupakan suatu saham yang manajemennya memiliki reputasi baik, pendapatan tinggi, konsisten membayar dividen tunai, dan umumnya merupakan emiten yang sudah mapan serta pemimpin dalam industrinya. Guna memudahkan pengenalan terhadap blue chip stock maka, BEI membentuk Indeks yang terdiri dari 45 saham unggulan yang mengacu pada dua variabel yaitu likuiditas perdagangan dan kapitalisasi pasar, diluncurkan pertama kali pada 24 Februari 1997.

Berdasarkan uraian sebelumnya, penelitian ini penting untuk dilakukan dalam mengetahui sejauh mana pengaruh variabel makro ekonomi dalam mempengaruhi return saham Indeks LQ 45 yang terdaftar di Bursa Efek Indonesia, maka

\section{KAJIAN PUSTAKA}

Setiap perusahaan membutuhkan pasar keuangan atau financial market untuk mendukung sumber dananya. Pasar keuangan terdiri dari pasar uang (money market) dan pasar modal (capital market). Pasar uang atau money market berkaitan dengan penyediaan dana - dana jangka pendek, sementara pasar modal atau capital market berkaitan dengan penyediaan dana - dana berjangka panjang. Sartono (2001:24) berpendapat bahwa: "Pasar modal adalah tempat terjadinya transaksi asset keuangan jangka panjang atau long term financial asset. Sedangkan pengertian klasik pasar modal adalah suatu bidang usaha perdagangan surat - surat berharga seperti saham, obligasi dan sekuritas efek.

Saham (stock) merupakan salah satu alternative investasi yang dapat menghasilkan keuntungan dalam bentuk dividen dan capital again. Apabila seorang investor membeli saham, maka menjadi pemilik dan disebut sebagai pemegang saham (shareholders) perusahaan yang menerbitkan saham tersebut. Azis, dkk (2015: 57) mengemukakan bahwa "saham adalah tanda penyertaan atau kepemilikan investor individual atau investor institusional atau trader atas investasi mereka atau sejumlah dana yang diinvestasikan dalam suatu perusahaan. Return merupakan selisih antara harga jual dengan harga beli (dalam persentase) ditambah kas lain (misalnya deviden). Fahmi (2012: 189) berpendapat bahwa return adalah keuntungan yang diperoleh oleh perusahaan, individu, dan institusi dari hasil kebijakan investasi yang dilakukannya.

Dikutip dari www.idx.co.id, Indeks harga saham adalah suatu indikator yang menunjukkan pergerakan saham. Indeks berfungsi sebagai indikator trend pasar, artinya pergerakan Indeks menggambarkan kondisi pasar pada suatu saat, apakah pasar sedang aktif atau lesu. Pergerakan indeks menjadi indikator penting bagi para investor untuk menentukan apakah mereka akan menjual, menahan, atau membeli suatu atau beberapa saham. Harga saham tersebut bergerak dalam hitungan detik dan menit, maka nilai indeks pun bergerak turun naik dalam hitungan waktu yang cepat.

Inflasi merupakan salah satu indikator ekonomi yang mempunyai pengaruh negatife secara tidak langsung terhadap emiten serta pasar modal. Dampak inflasi yang dirasakan langsung oleh perusahaan (inflasi terjadi dalam jangka panjang), yakni terjadinya pembengkakan biaya produksi perusahaan. Tingginya biaya ini akan berpengaruh pada harga produk perusahaan tersebut yang mengalami kenaikan. Naiknya harga barang ini belum tentu dapat diimbangi oleh kemampuan atau daya beli masyarakat yang sepadan. Jika hal ini terjadi, maka pastinya akan mempengaruhi profitabilitas perusahaan yang menurun, sehingga dividen yang diterima oleh shareholders pun akan mengalami penurunan dan berakibat pengalihan dana oleh investor pada investasi lain yang lebih menguntungkan. Kenyataan tersebut pasti akan berpengaruh terhadap harga saham yang tercantum dalam indeks LQ 45 yang nantinya juga akan mempengaruhi terhadap penurunan return saham perusahaan. Sesuai dengan 
pendapat yang dikemukakan Sunariyah (2006:22) bahwa, "Inflasi yang tinggi menyebabkan menurunnya profitabilitas suatu perusahaan, sehingga akan menurunkan pembagian dividen dan daya beli masyarakat juga menurun, sehingga inflasi yang tinggi, mempunyai dampak yang negative dengan pasar ekuitas".

Hubungan antara harga saham dengan investasi menurut Nopirin (2001:71), semakin tinggi bunga, keinginan untuk melakukan investasi juga semakin kuat. Alasan seorang pengusaha akan menambah pengeluaran investasinya apabila keuntungan yang diharapkan dari investasi lebih besar dari pada bunga yang harus dibayar untuk dana investasi, semakin rendah tingkat bunga maka pengusaha akan terdorong untuk melakukan investasi sebab biaya penggunaan dana juga semakin sedikit. Menurut Sunariyah (2002:31), tingkat bunga mempunyai hubungan negatife dengan sekuritas (IHSG)," jadi apabila bunga naik maka harga sekuritas akan turun, sebaliknya jika bunga turun akan mengakibatkan harga sekuritas naik yang nantinya hal ini akan berdampak pada tingkat return saham yang akan diperoleh perusahaan". Salah satu kebijakan moneter adalah penetapan tingkat suku bunga oleh bank sentral.

Nilai kurs adalah suatu nilai tukar mata uang asing terhadap mata uang lain. Demikian pula pertukaran antara dua mata uang yang berbeda dimana akan terdapat perbandingan nilai atau harga antara kedua mata uang tersebut. Pengaruh dari fluktuasi nilai rupiah terhadap nilai mata uang asing yang stabil maka akan mempengaruhi iklim investasi di dalam negeri. Jika terjadi apresiasi kurs rupiah terhadap Dollar misalnya, akan memberikan dampak terhadap perkembangan pemasaran terhadap produk Indonesia di luar negeri, terutama dalam hal persaingan harga. Apabila hal ini terjadi, maka secara tidak langsung akan memberikan pengaruh terhadap neraca perdagangan, karena nilai ekspor yang menurun dibandingkan dengan nilai impor. Selanjutnya, akan berpengaruh pada neraca pembayaran Indonesia. Memburuknya neraca pembayaran tentunya akan mempengaruhi cadangan devisa. Berkurangnya cadangan devisa maka akan mengurangi kepercayaan investor terhadap perekonomian Indonesia, yang selanjutnya menimbulkan dampak negative terhadap perdagangan saham di pasar modal yang mengakibatkan terjadinya capital outflow. Kemudian, jika terjadi penurunan kurs yang berlebihan, akan berdampak pada perusahaan - perusahaan go public yang menggantungkan faktor - faktor produksi terhadap barang impor. Besarnya belanja impor dari perusahaan seperti ini bisa mempertinggi biaya produksi serta terjadi penurunan terhadap laba perusahaan. Akhirnya dapat ditebak bahwa harga perusahaan itu akan anjlok yang nantinya menyebabkan return Indeks LQ 45 pun menurun.

Perubahan Jumlah Uang Beredar ditentukan oleh hasil interaksi antara masyarakat, lembaga keuangan dan Bank Sentral. Jumlah uang beredar adalah hasil kali uang primer (monetary base) dengan pengganda uang (money multiplier). Menurut teori Keynes, permintaan terhadap uang merupakan tindakan rasional. Meningkatnya permintaan uang akan menaikkan suku bunga. Investasi pada surat berharga (obligasi) pada saat suku bunga naik akan mengakibatkan kerugian capital gain, dan akan berdampak pula pada menurunnya return saham perusahaan.

\section{METODE PENELITIAN}

Variabel dependen dalam penelitian ini adalah return saham (Y) yang diambil dari tahun 20102015 dan variabel independen dalam penelitian ini adalah tingkat inflasi $\left(\mathrm{X}_{1}\right)$, tingkat suku bunga $\left(\mathrm{X}_{2}\right)$, nilai tukar rupiah $\left(\mathrm{X}_{3}\right)$ dan jumlah uang beredar $\left(\mathrm{X}_{4}\right)$, yang bersumber dari website resmi Bank Indonesia (http://www.bi.go.id) meliputi data tingkat inflasi, tingkat suku bunga, nilai tukar rupiah, dan jumlah uang beredar.website Duniainvestasi.com dan IDX LQ45 yang meliputi data harga saham Indeks LQ 45.

Populasi penelitian ini adalah perusahaan yang listing pada Indeks LQ 45 di Bursa Efek Indonesia selama periode 2010-2015 yang berjumlah 45 perusahaan. pengambilan sampel menggunakan metode purposive sampling, dimana sampel diambil berdasarkan kriteria tertentu dengan jumlah perusahaan yang dijadikan sampel yaitu 24 perusahaan dengan tahun pengamatan selama 6 periode dengan hasil penarikan sampel yaitu 144 sampel. Penelitian ini menggunakan analisis regresi linear berganda dengan melakukan uji asumsi klasik yang terdiri dari uji Normalitas, uji Heteroskedastisitas, uji Multikolinearitas dan uji Autokorelasi. 


\section{HASIL DAN PEMBAHASAN}

Pada tabel 1 menunjukkan bahwa Return saham sebagai variabel dependen (Y) memiliki nilai rata - rata 0.12 dan standar deviasinya sebesar 0.63 . Rata - rata nilai untuk variabel independen yaitu Inflasi tahun 2010 - 2015 adalah 5,69 \% dengan standar deviasi sebesar 1,79\%. Tingkat Suku Bunga sebagai variabel independen berikutnya yang memiliki pengaruh pada return saham dengan rata - rata sebesar $6,66 \%$ dan standar deviasi $0,73 \%$.

Tabel 1. Inflasi, Suku Bunga, Nilai Tukar, Jumlah Uang Beredar dan Return Saham

\begin{tabular}{cccc}
\hline Variabel & Mean & Std. Deviation & $\mathrm{N}$ \\
\hline Return & .1245 & .63265 & 144 \\
Inflasi & 5.6900 & 1.78946 & 144 \\
Bunga & 6.6667 & .73380 & 144 \\
Kurs & 9.1100 & 8.93820 & 144 \\
Uang & 14.4450 & 2.34490 & 144 \\
\hline
\end{tabular}

Sumber: Output SPSS, data olahan

Nilai tukar rupiah terhadap Dollar Amerika rata - rata selama periode pengamatan adalah 9,11 $\%$ dan standar deviasinya sebesar $8,94 \%$. Selama pengamatan penelitian rata - rata jumlah uang beredar sebesar $14,44 \%$ dengan standar deviasi sebesar $2,34 \%$.
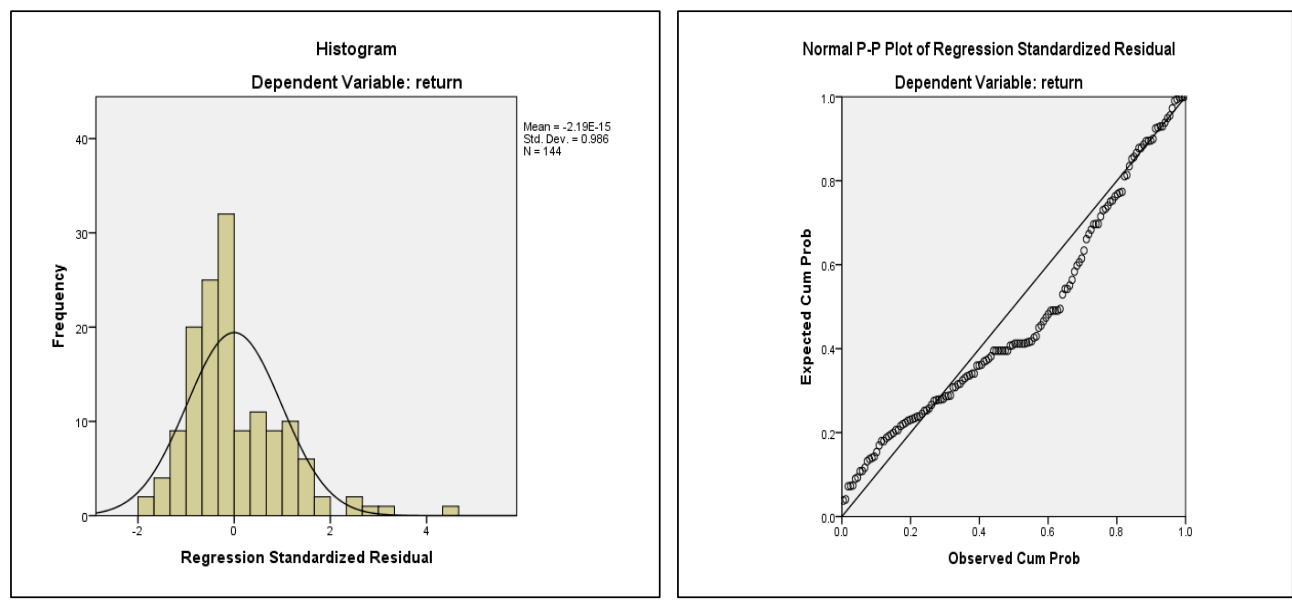

Gambar 2. Histogram dan Normal P- Plot

Sumber: data sekunder diolah (spss)

Dengan melihat grafik histogram maupun grafik normal plot pada gambar: 2 diatas maka disimpulkan bahwa grafik histogram memberikan pola distribusi yang normal dan grafik normal plot terlihat titik menyebar sekitar garis diagonal, serta penyebarannya mengikuti arah garis diagonal menunjukkan model regresi penelitian ini layak dipakai karena memenuhi asumsi normalitas.

Suku bunga mempunyai $t$ hitung sebesar 2.509 dengan tingkat signifikansi 0.013 dan koefisiensi 0.356 sehingga dapat disimpulkan bahwa suku bunga berpengaruh positif signifikan terhadap return saham Indeks LQ 45 periode selanjutnya. Hasil penelitian ini menyatakan bahwa jika terjadi kenaikan terhadap suku bunga, maka terjadi peningkatan pada return saham Indeks LQ 45. Hasil penelitian ini mendukung dengan penelitian sebelumnya yaitu Satria (2016) yang menyatakan dalam penelitiannya bahwa suku bunga memiliki pengaruh positif signifikan terhadap return saham perusahaan food and beverages di Bursa Efek Indonesia dan tidak sejalan dengan peneltian Hendra (2013) yang menemukan adanya pengaruh negative signifkan antara suku bunga terhadap return saham pada perusahaan property serta pada penelitian Halim (2013) yang menyatakan bahwa suku bunga tidak mempunyai pengaruh signifikan terhadap return saham. 
Nilai tukar rupiah terhadap kurs Dollar Amerika mempunyai $\mathrm{t}_{\text {hitung }}$ sebesar 0.936 dengan tingkat signifikansi 0.351 dan koefisien regresi 0.011 sehingga dapat disimpulkan bahwa nilai tukar rupiah terhadap Dollar Amerika berpengaruh tidak signifikan terhadap return saham Indeks LQ 45. Hal ini sejalan dengan penelitian Hendra (2013) dan Satria (2016) yang menyatakan dalam penelitiannya bahwa nilai tukar rupiah tidak berpengaruh signifikan terhadap return saham.

Jumlah uang beredar mempunyai $\mathrm{t}$ hitung sebesar -0.551 dengan tingkat signifikansi 0.583 lebih besar dari 0.05 dan nilai koefisien -0.027, sehingga dapat disimpulkan bahwa jumlah uang beredar berpengaruh tidak signifikan terhadap return saham Indeks LQ 45 pada periode selanjutnya. Temuan ini sejalan dengan penelitian dari Sunaryo (2013) yang menyatakan bahwa jumlah uang beredar tidak berpengaruh siginifikan terhadap return saham pada Indeks Harga Saham Gabungan (IHSG). Dan tidak sejalan dengan penelitian Halim (2013) yang menyatakan bahwa jumlah uang beredar berpengaruh signifikan terhadap return saham kapitalisasi besar di Bursa Efek Indonesia. Hal ini menunjukkan bahwa jumlah uang beredar di Indonesia tidak mempengaruhi kinerja pasar saham pada tahun 2010 - 2015. Artinya bahwa masyarakat Indonesia tidak menggunakan uangnya untuk tujuan spekulatif, yaitu dengan membeli saham.

\section{SIMPULAN}

Inflasi, suku bunga, nilai tukar rupiah dan jumlah uang beredar secara bersama -sama memiliki pengaruh yang signifikan terhadap variable independen. Hal ini dapat dijelaskan dari nilai $\mathrm{f}_{\text {hitung }}$ lebih besar daripada $\mathrm{f}_{\text {table }}$ dengan nilai signifikansi 0.000 dengan probabilitas yang jauh lebih kecil dari $\alpha=5$ $\%$ atau 0.05 .

Inflasi berpengaruh negative signifikan terhadap return saham Indeks LQ 45. Peningkatan persentase inflasi akan membuat masyarakat cenderung untuk mengamankan uangnya dan lebih banyak digunakan untuk kebutuhan hidupnya, sehingga minat masyarakat untuk berinvestasi menjadi menurun dan pada akhirnya akan berdampak pada menurunnya return saham.

Suku bunga berpengaruh positif dan signifikan terhadap return saham Indeks LQ 45. Peningkatan tingkat suku bunga akan berdampak pada meningkatnya investasi dan aktifitas ekonomi yang akan menyebabkan naiknya Indeks LQ 45. Sunariyah (2002:64) menyatakan bahwa pemerintah dapat mengendalikan permintaan dan penawaran dengan menetapkan bunga bank. Dalam hal ini bunga bisa disesuaikan oleh pemerintah. Pada saat permintaan tinggi, sirkulasi uang dimasyarakat terlalu besar, maka pemerintah dapat menaikkan suku bunga agar penawaran uang meningkat dan permintaan uang menurun.

Nilai tukar rupiah terhadap Dollar Amerika berpengaruh tidak signifikan terhadap return saham Indeks LQ 45. Peningkatan nilai tukar rupiah terhadap Dollar Amerika tidak dapat mempengaruhi peningkatan return saham Indeks LQ45.

Jumlah uang beredar berpengaruh tidak signifikan terhadap return saham yang diperoleh investor sehingga nilai kurs rupiah bukan merupakan variabel yang perlu diperhatikan investor saat akan berinvestasi kedalam bentuk saham pada Indeks LQ 45.

\section{DAFTAR PUSTAKA}

Abdul, Halim. 2005. Analisis Investasi, Edisi Kedua. Salemba Empat, Jakarta.

Anoraga, Pandji dan Piji Pakarti. 2006. Pengantar Pasar Modal, Rineka Cipta, Jakarta.

Azis, Musdalifah, Sri Mintarti, dan Maryam Nadir. 2015. Manajemen Investasi Fundamental,

Teknikal, Perilaku Investor Dan Return Saham, Ed.1, Cet.1, Deepublish, Yogyakarta.

Baridwan, Zaki, 2004. Intermediate Accounting, Ed. 8, BPFE, Yogyakarta.

Choi, Frederick. 1999. Akuntansi Internasional, Ed.4, Buku 1, Salemba Empat, Jakarta.

Darmawi, Herman. 2006. Pasar Finansial dan Lembaga - Lembaga Finansial, Bumi Akasara, Jakarta.

Darmadji, Tjiptono dan Hendy M. Fakhrudin. 2006. Pasar Modal Indonesia: Pendekatan Tanya Jawab, Ed. Kedua, Salemba Empat, Jakarta.

Darmadji, 2001. Pasar Modal di Indonesia: Pendekatan Tanya Jawab, Ed. Pertama, Salemba Empat, Jakarta. 
Daryono, Soebagyo. 2003. Analisis Faktor - Faktor yang Mempengaruhi IHSG, Jurnal

Ekonomi

Pembangunan 4 (2).

Dornbusch, R. dan S. Fischer.1992. Makroekonomi. Terjemahan, Erlangga, Jakarta.

Ghozali, Imam. 2005. Aplikasi Analisis Multivariat Dengan SPPS, Ed. Ketiga, Badan Penerbit Universitas Diponegoro, Semarang.

Gitosudarmo, Indriyo dan Basri. 2002. Manajemen Keuangan, Ed.4, BPFE, Yogyakarta.

Gusti, I, Ayu Amanda Yulita Asri. 2014. Pengaruh Faktor Fundamental dan Ekonomi Makro Pada Return Saham Perusahaan Consumer Good. E-Jurnal Akuntansi Universitas Udayana.8.3(2014) :353 - 370 .

Halim, Abdul, 2005. Analisis Investasi, Edisi Kedua. Salemba Empat. Jakarta.

Halim, Livia, 2013. Pengaruh Makro Ekonomi Terhadap Return Saham Kapitalisasi Besar Di Bursa Efek Indonesia. Jurnal FINESTA Vol. 1, No. 2 (2013): 108 - 113.

Harjito, Agus. 2009. Keuangan Perilaku Menganalisis Keputusan Investor, Edisi Pertama, EKONOSIA, Yogyakarta.

Hendra, Tri Purnomo dan Nurul Widyawati, 2013.Pengaruh Nilai Tukar, Suku Bunga Dan Inflasi Terhadap Return Saham Pada Perusahaan Properti. Jurnal Ilmu \& Riset Manajemen Vol. 2, No. 10 (2013).

Huang, Stanley. S.C (Trans) Yohannes, 2003. Timing the Stock Market for Maximum Profit Probus Publishing Company, Chicago, Lillion, USA.

Huda, Nurul 2008.Ekonomi MakroIslam: Pendekatan Teoritis. Ed. 1, Kencana, Jakarta.

Jogiyanto, Sartono. 2010. Teori Portofolio Dan Analisis Investasi, Ed.7, BPFE. Yogyakarta.

Kasmir. 2011. Bank dan Lembaga Keuangan Lainnya, Edisi Revisi, cetakan ke sebelas, RAJAWALI PERS, Jakarta.

Martono, dan Agus Hartijo. 2001. Manajemen Keuangan, Ekonosia, Yogyakarta.

Muhammad, Samsul, 2008. Pasar Modal Dan Manajemen Portofolio. Erlanga, Jakarta.

Nazwar, Chairul, 2008. Analisis Pengaruh Variabel Makroekonomi Terhadap Return Saham Syariah

Di Indonesia. Jurnal Perencanaan \& Pengembangan Wilayah, Vol.4, No.1, Agustus 2008.

Nopirin. 1987. Ekonomi Moneter, Buku II, Ed. Kesatu, BPFE, Yogyakarta.

Nopirin, 1999. Ekonomi Moneter, Jilid 1, Ed. Kedelapan, BPFE, Yogyakarta.

Nopirin, 2000. Ekonomi Moneter. Buku II, Ed. Pertama, Cetakan Kesepuluh, BPFE, Yogyakarta.

Nopirin, 2007. Ekonomi Moneter. Buku I, Ed. Keempat, Cetakan Kedelapan, BPFE, Yogyakarta.

Octavia, Ana. 2007. Analisis Pengaruh Nilai Tukar Rupiah / \$ dan Tingkat Suku Bunga SBI terhadap Indeks Harga Saham Gabungan di BEJ. Skripsi, UNS, Semarang.

Prihantini, Ratna, 2009. Analisis Pengaruh Inflasi, Nilai Tukar, ROA, DER, Dan CR Terhadap Return Saham (Studi Kasus Saham Industri Real Estate and Property yang Terdaftar di Bursa Efek Indonesia Periode 2003 - 2006. Tesis, Universitas Diponegoro.

Rangkuti, Freddy, 2007. Riset Pemasaran, PT. Gramedia Pustaka Utama, Jakarta.

Rahardja, Pratama dan Mandala Manurung. 2004. Teori Ekonomi Makro.

Rusdin, 2006. Pasar Modal, Alfabeta, Bandung.

Rofiana, Sinta, 2009. Pengaruh Faktor - Faktor Makro Ekonomi Terhadap Return Saham - Saham Jakarta Islamic Index (JII) Periode 2004 - 2006 Menggunakan Arbitrage Pricing Theory (APT). Skripsi, Universitas Islam Negeri Sunan Kalijaga Yogyakarta.

Saini, Azwan., Muzawar Shah Habibullah dan M. Azali, 2002. Stock Price and Exchange rate Interaction in Indonesia: An empiri Inquary, Jurnal Ekonomi dan Keuangan Indonesia, Vol.1, No. 3, Hal 311 - 324.

Sartono, Agus. 2001. Manajemen Keuangan Teori dan Aplikasi, Ed.4, BPFE, Yogyakarta.

Satria, Made Wiradharma A dan Luh Komang Sudjarni, 2016. Pengaruh Tingkat Suku Bunga, Tingkat Inflasi, Nilai Kurs Rupiah dan Produk Domestik Bruto Terhadap Return Saham.

E - Jurnal Manajemen Unud. Vol. 5, No. 6, 2016: 3392 - 3240.

Sugiyono, 2011. Statistika Penelitian, Cetakan Kedelapan belas, Alfabeta, Bandung.

Sunariyah.2002. Pengantar Pengetahuan Pasar Modal, Ed. Kedua, YKPN, Yogyakarta.

2006. Pengantar Pengetahuan Pasar Modal, Ed. Kelima, UPP STIM YKPN, Yogyakarta. 
Sunaryo, 2013. Analisis Pengaruh Variabel - Variabel Ekonomi Makro Terhadap Return Saham. Jurnal BINUS BUSINESS REVIEW Vol. 4, No. 1, Mei 2013: 541 - 550.

Sutrisno, 2007. Manajemen Keuangan, Cetakan Kelima, Ekonosia, Yogyakarta.

Tandelilin, Eduardus. 2001. Analisis Investasi dan Manajemen Portofolio, Ed.1, BPFE, Yogyakarta. Yuliadi, Imamudin. 2008. Ekonomi Moneter, PT. Index Jakarta.

http: // www.pasarmodal.com. Di akses tanggal 20 Februari 2016

http: // www.bi.go.id. Di akses tanggal 23 Maret 2016

http: // www.idx.co.id. Di akses tanggal 12 Oktober 2016

http: // www.duniainvestasi.com. Di akses tanggal 1 September 2016 